\title{
Effectiveness of the Training Program for the Women's Outwear Manufacturers to serve the small-scale Industries
}

\author{
Rania Mostafa Kamel Abdel Aal
}

Lecturer in the department of Clothing \& Textile- Faculty of Home economics Helwan University

\section{Introduction:}

The world is the era of accelerating the pace of change and development, and no doubt that the most important tools for change and development is the effective training of manpower as the most important element of energy development and the most important institutions, which are paid to achieve its objectives in all countries of the world (Abdel-Moneim, 1996).

The manpower is the most important elements of the economic process and social development. Where researches tend to the necessity of activating the human power through a proper planning and to accommodate changes and adapt administrative systems and rehabilitation programs with the requirements of development. (www.hrdf.org.sa)

For human capacity development, must support the development process through all the organs of state and private educational institutions to develop services in line with the needs of industry, especially the garment industry which has many characteristics and attributes that qualify it to be one of the drivers behind the wheel of human development in Egypt. (Mohammad, 2002).

The training of human resources is considered as effective trends that contribute to increase production efficiency because it is in response to changes in the external environment. As a result of the current world of rapid global changes and the application of the convention on the global trade liberalization and technology revolution, was necessary to promote small businesses as a way to solve many economic problems.

Therefore, it is necessary to develop trained technical staff can contribute to the wheels of development, because the human element is the basis of the development process particularly in the garment industry, which is considered as a fundamental pillar for building the future. Where is represents the most important economic sectors, which attract great attention from all over the world.

The training is defined as those efforts that aim to provide the trainer with information and knowledge to gain skills in the performance of work or development and the development of his skills, knowledge and experience as to 
increase the efficiency in the performance of his current or be prepared to perform the action with a higher level.

Training is a strategic choice to anyone looking forward to the preparation of human cadres capable of meeting the needs of work and keep abreast of developments and rapid changes that occur in different areas.

Training creates trainee knowledge and new skills required by the profession for up to a level that aspire to any party seeking to advance the progress. Where that training is essential for the learner and development of the human race and then the progress and build of society will be done. (www.suwaidan.com)

\section{Training Objectives:}

Training objectives are divided into three main groups:

1 - Traditional goals:

- Training new employees in their fields and keep pace with scientific and technological progress, by providing trainees with information during their work or skills when you enter certain modifications in the methods of work.

$r$ - The goals of solving problems:

- Search for the best ways to help workers to overcome the problems they face.

3 - Creative objectives:

- It aimed to achieve high levels of business, through the use of sophisticated scientific methods, and distinctive elements capable of innovation and creativity.

The training system consists of five basic elements, namely:

1 - Goal of the training: means the specific results in time, space, quality, and training system, which seeks to achieve them.

2 - Inputs to the training process: It consists of the human elements (trainers, trainees); physical elements (equipment and funds), and elements of the significance (studies, facts and problems).

3 - The processes necessary for implementation: includes the preparatory processes for the train to get to know the possibilities, then the operational 
processes of transfer of knowledge, skill and experience and, finally, a followup complementary processes and performance appraisal training.

4 - Output the training process: It means the trainees to acquire skills and new directions, and then increased performance and improved methods of work and the spirit of productivity and profitability.

5 - Returns impact: a comparison of the output resulting from the training and pre-defined objectives as well as the statement of deviations with adjusted constantly.

\section{Training systems:}

\section{Training system to include:}

1 - Identification of training needs.

2 - Design the training program.

3 - The implementation of the training program.

4 - Evaluation of the trainee. (www.hrdiscussion.com)

5 - The training programs are evaluated on the steps:

- Prior to implementation: to measure the success of the preparation.

- During implementation: in terms of time allocated to training, and training techniques used to ascertain the suitability of the implementation process with the plan.

- After implementation: to stand on its training program objectives and their success in meeting training needs.

The role of universities is the greatest common denominator in any operations for the overall development as it is primarily concerned with the development of trained human resources to boost production, (Hatem, 1999).

Based on the above mentioned the author prepared a training program for the production of clothes trousers on a scientific basis for graduates wishing to set up small businesses in an effort to advance human development.

\section{Research problem:}


There is clearly the research problem in the following questions:

- What is the scientific basis upon which the program to give graduates the knowledge and skills for the production of women's blouse for the establishment of small projects?

- What is the content of the training program?

- To what extent the program's effectiveness in giving the trainees the knowledge and skills necessary to produce the women's blouse?

\section{Research Objectives:}

- Determine the effectiveness of a training program based on scientific bases to give graduates the knowledge and skills for the production of women's blouse.

- Prepare and qualify graduates and equip them with knowledge and skills required by the labor market.

- Support for small-scale industries and to contribute to solving the unemployment problem.

\section{The importance of research:}

The importance of this research lies in the preparation of qualified technical staff to cope with the incident in the garment industry and the opportunity for them to work and improve the level of performance as well as to the establishment of small projects have a positive impact on national income.

\section{Hypotheses:}

1 - There are significant differences between the average scores of trainees in the knowledge gained on forging the model before and after training for the post test

2 - There are significant differences between the average scores of trainees in the knowledge gained special implementation techniques before and after training for the post test

3 - There are significant differences between the average scores of trainees in the knowledge acquired before and after training for the post test 
4 - There are significant differences between the average scores of trainees in the skills acquired on forging the model before and after training for the post test

5 - There are significant differences between the average scores of trainees acquired skills in the implementation of special techniques before and after training for the post test

6 - There are significant differences between the average scores of trainees in the skills acquired before and after training for the post test

7 - There are significant differences between the average scores of trainees program before and after training for the benefit of the post

\section{Search procedures:}

\section{Research Methodology:}

These experimental methods follow the Experimental method for their suitability in achieving the objectives of the research and verification of hypotheses.

\section{Sample of the research:}

The program has been applied to (30) of qualified graduates' girls with high and medium education level at the Higher Institute of Applied Arts from 15/08/2009 for a period of five weeks (three times/week -three hours / day).

\section{Search Tools:}

- The training program.

- A test knowledge (before / post).

- A practical skill test (before / post).

- Measure of appreciation.

\section{Search limits:}

- The search is limited on the study (women's blouse) in terms of preparation flat Pattern and study of the techniques for implementation.

- The training of graduates of higher and middle education level. 


\section{Search Terms:}

Training program: is the activity of a renewed and sustained planning begins and ends with monitoring and evaluation. Which aimed at developing knowledge and skills of individual and collective by its effect on behavior with a positive impact and effectiveness is measured as much as can be applied, (Ali and Aida, 2002).

Small Industries: there are many definitions and concepts, and usually the definition of small-scale industry by the employment size or the amount of capital invested in fixed assets.

Moreover, the small-scale industries can be defined as in the modern sense as (those industry that accept the development and improvement in line with the wishes of the arts of production and the level of consumer with an average in capital intensity), (http://www.alhadag.com/column.php?id=422)

\section{Search procedures:}

\section{First: the preparation of the training program:}

The author set up a training program to give graduates the knowledge and skills-building and implementation of the Pattern of women's blouse .

\section{A - Determine the program's topic:}

The program has chosen in line with the trends, which calls for the development of human resources and support for small industries.

\section{b- Determine program objectives}

\section{The general objectives of the program:}

After completion of the training that the trainee can:

- Recognize the concepts of the garment industry.

- Recognize the foundations to be followed when building the women's blouse pattern.

- Draw the women's blouse pattern .

- To work in R.M.G. factories . 


\section{Procedural goals of the program:}

After the training the trainee will be able to:

- Take body measurements in a scientifically sound.

- Known as the scientific basis for divisions on sizes taken for the preparation of Pattern.

- Defines forms pockets.

- Mastered the work of the Panda Pocket

- Recognize the concept of sjav.

- Recognize the forms of refrain.

- Compares the coller (Oovise - Sport Chimisais - flatbed).

- Specify the types of sleeves.

- The types of cuff .
- Know the Pattern and trends.

- Recognize the pied

- Write data on the parts of the Pattern.

- Determines the direction of the fabric.

- Recognize the different folds of the tail.

- Recognize the concept of ruffles.

- Specifies the sizes of fragments.

- Recognize the concept of sjav (fragments minute).

- Identifies the various tools closure.

\section{Kinetic targets of the program:}

The trainee after completion of the program is able to lead the following skills:

- Raise the measurements properly.

- Draw the Pattern a sound scientific manner (in front of - behind - sleeve).

- Writes the data on Pattern parts.

- The cutting and installation of sjav.

- The weaving refrain

- Pastes stuffing coller

- The installation of coller
- Cut Pattern parts and put it on the cloth properly.

- The process of being clutch parts Pattern correctly.

- Flex the tail.

- Mastered the process of ruffles.

- Weaving fragments.

- Mastered the nerver

- The installation of the appropriate 
-The installation of sleeves

- Mastered the installation bracelets tools sealed (zippers - buttons).

- Performs sample pocket with Band.

- Cutting and installation of sjav.

\section{Content of the training program:}

The program included training on the following topics:

- Identify the concepts related to the - Prepare pied bar. preparation Pattern.

- Identify the concepts related to garment sample. industry.

- Identify the steps to be followed for the construction of Pattern statute.

- Preparation of women's blouse Patern (Korsag).

- The concept of panda.

- Sample preparation of pocket with panda.

- The concept of sjav.

- Preparation of coller Patern.

- Sample preparation sjav.

- Preparation of women's blouse pattern (sleeve).

- Identify the methods interleave (sleeve) model on the canvas.

- To identify the different folds of the tail.

- Sample preparation ruffle.

- Understand the concept of fragment.

- The implementation of the ruffle samples with different sizes.

- Refrain concept.

- The implementation of the refrain sample.

- The concept of coller.

- Forms coller.

- Implementation of samples coller

- The concept of sleeve.

- Forms of the sleeve.

- Installation of sleeve.

- The concept of bracelets.

- Installation of decorative zipper.

- Types of bracelets

- Preparation of a sample installation of the buttons.

- Installation of bracelets. 


\section{Timeline for Training}

\begin{tabular}{|c|c|c|c|c|c|c|c|c|c|c|c|c|c|c|c|}
\hline \multirow[t]{2}{*}{$\begin{array}{l}\text { Content of the training } \\
\text { program }\end{array}$} & \multicolumn{3}{|c|}{ First week } & \multicolumn{3}{|c|}{$\begin{array}{l}\text { Second } \\
\text { week }\end{array}$} & \multicolumn{3}{|c|}{ Third week } & \multicolumn{3}{|c|}{$\begin{array}{l}\text { Fourth } \\
\text { week }\end{array}$} & \multicolumn{3}{|c|}{ Fifth week } \\
\hline & 1 & 2 & 3 & 1 & 2 & 3 & 1 & 2 & 3 & 1 & 2 & 3 & 1 & 2 & 3 \\
\hline $\begin{array}{l}\text { 1-Understand the basic } \\
\text { concept of Pattern } \\
\text {-Understand the concept of the } \\
\text { clothing industry } \\
\text { - Steps to be followed to } \\
\text { obtain Basic Pattern }\end{array}$ & $\sqrt{ }$ & & & & & & & & & & & & & & \\
\hline $\begin{array}{l}\text { 2- Drawing the basic model of } \\
\text { the blouse (front - back - } \\
\text { sleeve - collar) }\end{array}$ & & $\checkmark$ & & & & & & & & & & & & & \\
\hline $\begin{array}{l}\text { 3- Identify the different folds } \\
\text { - Sample numbers pagan } \\
\text { tail } \\
\text { - Sample preparation } \\
\text { ruffles }\end{array}$ & & & $\checkmark$ & & & & & & & & & & & & \\
\hline $\begin{array}{l}\text { The concept of Kasra (shards) } \\
\text { - Sample preparation shards of } \\
\text { various sizes } \\
\text { - The number of sample } \\
\text { Nerver ( micro shards) }\end{array}$ & & & & $\checkmark$ & & & & & & & & & & & \\
\hline $\begin{array}{l}\text { - To identify the different } \\
\text { forms of tools closure } \\
\text { - Installation of decorative } \\
\text { zipper }\end{array}$ & & & & & $\checkmark$ & & & & & & & & & & \\
\hline $\begin{array}{l}\text { Concept pied } \\
\text { Preparation of pied } \\
\text { - The implementation of the } \\
\text { pied sample }\end{array}$ & & & & & & $\checkmark$ & & & & & & & & & \\
\hline
\end{tabular}




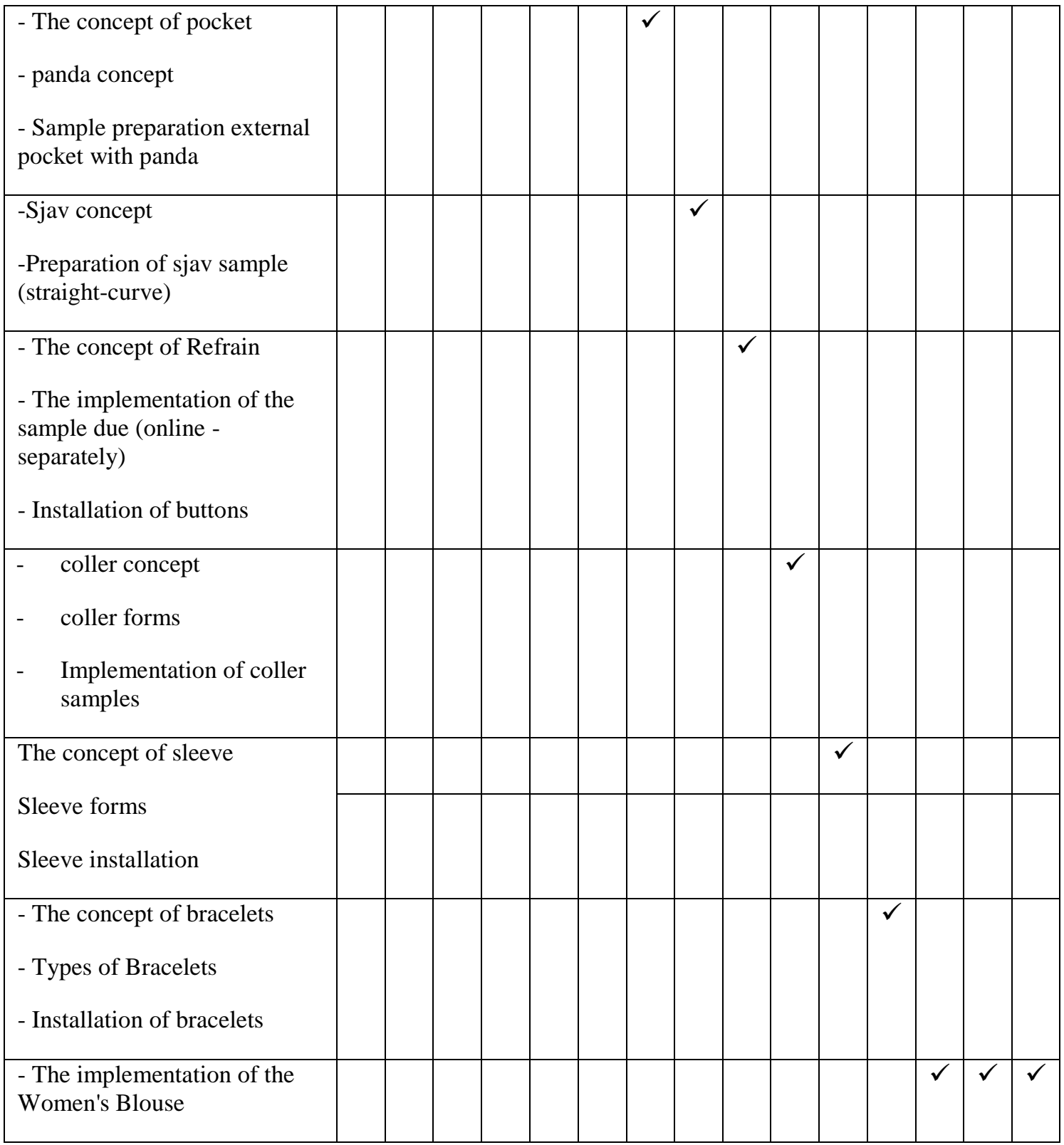

\section{Assess and evaluate the program:}

The program has been demonstrated on a group of specialized professors to make sure the integrity of the scientific and technical aspects. The specialized professors agreed on the validity of the whole program after making minor amendments which, have been done. 


\section{To gauge the validity of the program has been prepared:}

- Cognitive achievement test, which included a series of questions about setting Pattern and enforcement techniques. The questions are about thirty multiple choice questions, which were patch according to the key and select the correct question for each one degree only.

- Skill test, the test contains two questions one of each for preparing Women's blouse Patern and other techniques for the implementation of the Women's blouse. The test has been corrected according to the scale skills assessment of each part of the skill test.

- Measure of appreciation, appreciation of the scale contains over twenty points of model,and twenty points, especially techniques used to implement the blouse.

The correction was done by three specialists, by mark in front of each point (exact, exact to some extent, is not set) by (two degrees -one degree - zero), respectively.

\section{Validity and reliability of the achievement test of knowledge:}

\section{1 - Honesty:}

\section{Logical validity:}

- The achievement test has been demonstrated to a jury of specialized professors on a purpose of ascertaining the extent of ease and clarity of testing, and a link questions to the test goals. The arbitrators were unanimous on the validity of the achievement test with the application to make some proposals; the modification has been done based on the following proposals:

- Reduce the number of questions.

- taking into account the ease and clarity of the wording.

\section{2 - Stability:}

Stability is intended to be coordinated with the test gives the results, were calculated reliability coefficient achievement test in the following ways:

\section{A - Using the retail mid-term stability:}

The stability of achievement knowledge test is confirmed using the retail midterm, and the values of the correlation coefficient were $0.715-0.834$ on the 
portion of fee model while, 0.757 - 0.861 techniques for implementation of the values of a function at a level of 0.01 approaching to one, which indicates the persistence of the achievement test of knowledge.

\section{b - Constant alpha coefficient:}

The alpha coefficient is found equal to 0.808 for part of Pattern drawing, and 0.847 for the implementation techniques. Theses are high values and this is proof the stability of the achievement test at the 0.01 level for approaching the values from the correct one, and the following table shows the values of stability

Table (1) test the stability of cognitive

\begin{tabular}{|c|c|c|c|c|}
\hline stability of cognitive test & \multicolumn{2}{|c|}{ Mid-term retail } & \multicolumn{2}{|c|}{ Alpha coefficient } \\
\hline Graphic form & $\cdot, \wedge \ll \varepsilon-\cdot, \vee \backslash 0$ & $\cdot, \cdot 1$ & $\cdot, \wedge \cdot \wedge$ & $\cdot, \cdot 1$ \\
\hline Enforcement techniques & 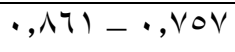 & $\cdot, \cdot 1$ & $\cdot, \wedge \leqslant \vee$ & $\cdot, \cdot 1$ \\
\hline
\end{tabular}

Validity and reliability of the applied skills test:

\section{1 - Honesty:}

Logical validity: the test is displayed on a group of professors which, recognized the validity of all of the application.

\section{2 - Stability:}

\section{Stability graders:}

The reliability coefficient correctors can be obtained by calculates the correlation coefficient between the scores given by the two Correctors or more of the same individuals or for the same tests. In other words, each examined, gets two degrees or more of the correct one test, the applied stability test was calculated by evaluating the Pattern of the individuals trainees.

The correction was done by three professors of arbitrators, using a scale appreciation in the evaluation process and the corrector has done the each evaluation process alone.

The correlation coefficient was calculated between the three grades established by the correctors $(\mathrm{x}, \mathrm{y}, \mathrm{z})$ of the applied test, using the dimensional correlation coefficient level for each model separately and the following table illustrates this: 
Table (2) the correlation coefficient between the correctors of the parts of the skill test

\begin{tabular}{|c|c|c|c|}
\hline correctors & Graphic form & Enforcement techniques & Skill test as a whole \\
\hline $\mathrm{x}, \mathrm{y}$ & $\cdot, \wedge \wedge 1$ & $\cdot, \wedge r q$ & $\cdot, \vee \vee १$ \\
\hline $\mathrm{X}, \mathrm{Z}$ & $\cdot, V \leqslant r$ & $\cdot, \vee Y Y$ & $\cdot, 9 Y \wedge$ \\
\hline $\mathrm{y}, \mathrm{z}$ & $\cdot, 9.9$ & $\cdot, \vee \vee \neg$ & $\cdot, \wedge \cdot 1$ \\
\hline
\end{tabular}

Is clear from the preceding table, the high values of correlation coefficients between the correctors, which range between $(0.736-0.928)$, the values of a function at a level of 0.01 approaching to one, which indicates the stability of the practical test, which measures the performance skills, and also demonstrates the stability of the scale of assessment which is a tool Patch of testing skills.

\section{Results}

First hypothesis: the first hypothesis is as follows:

"There are significant differences between the average scores of trainees program before and after training for the benefit of the post".

To investigate this hypothesis " $\mathrm{T}$ " test is applied, the following table illustrates this:

Table (3) significant differences between the mean scores of the trainees program before and after training

\begin{tabular}{|c|c|c|c|c|c|c|}
\hline $\begin{array}{c}\text { Total } \\
\text { "Knowledge } \\
\text { - Skill" }\end{array}$ & Mean & $\begin{array}{c}\text { Standard } \\
\text { Deviation } \\
\text { "sd" }\end{array}$ & $\begin{array}{c}\text { Number of } \\
\text { respondents } \\
\text { "n" }\end{array}$ & $\begin{array}{c}\text { Degree } \\
\text { of } \\
\text { freedom } \\
\text { "df" }\end{array}$ & $\begin{array}{c}\text { T } \\
\text { value }\end{array}$ & $\begin{array}{c}\text { Significance } \\
\text { level and } \\
\text { direction }\end{array}$ \\
\hline before & 7.371 & 1.966 & $r \cdot$ & $r q$ & 29.625 & $\begin{array}{c}0.01 \text { for } \\
\text { dimensional }\end{array}$ \\
\hline after & 54.771 & 8.482 & & & & \\
\hline
\end{tabular}

As seen from the table (3), the " $\mathrm{T}$ " value is equal to "29.625" which is statistically significant at 0.01 levels, where the average scores of trainees in the 
post "54.771" while the average scores of trainees in the application of before "7.371", which indicates to the existence of real differences between the two applications for the post. This means that the training program in this study is successful in achieving the goal of it and already knew the lines contained in respect of knowledge and skills.

To find out the size of the impact of the training program ETA equation was implemented: $(\mathrm{T})$ value $=29.625$, and degrees of freedom $(\mathrm{df})=29$

The impact magnitude is determined as follows:

$0.2=$ small effect size

$0.5=$ medium effect size

$0.8=$ large effect size

This means that the size of the impact of the training program is significantly large, and thus achieved the first hypothesis. This finding corresponds with studies carried out in various areas, which addressed the effectiveness of training as emphasizes by "Abdel Fattah, 1997" The training program aims to improve the skills and enrich the individual information.

The second hypothesis: the second hypothesis is as follows:

"There are significant differences between the average scores of trainees in the knowledge gained on forging the model before and after training for the post test."

To verify the validity of this hypothesis, " $\mathrm{T}$ " test has been applied and the following table illustrates this: 
Table (4) significant differences between the mean scores of the trainees in the knowledge gained special with drawing the Pattern before and after training

\begin{tabular}{|c|c|c|c|c|c|c|}
\hline $\begin{array}{c}\text { Graphic } \\
\text { form }\end{array}$ & $\begin{array}{c}\text { Mean } \\
\text { "m" }\end{array}$ & $\begin{array}{c}\text { Standard } \\
\text { Deviation } \\
\text { "sd" }\end{array}$ & $\begin{array}{c}\text { Number of } \\
\text { respondents } \\
\text { "n" }\end{array}$ & $\begin{array}{c}\text { Degree } \\
\text { of } \\
\text { freedom } \\
\text { "df" }\end{array}$ & $\begin{array}{c}\mathrm{T} \\
\text { value }\end{array}$ & $\begin{array}{c}\text { Significance } \\
\text { level and } \\
\text { direction }\end{array}$ \\
\cline { 1 - 2 } before & $\mathbf{1 . 8 1 7}$ & $\mathbf{1 . 1 1 7}$ & r. & rq & $\mathbf{4 0 . 2 5 1}$ & $\begin{array}{c}0.01 \text { for } \\
\text { dimensional }\end{array}$ \\
\cline { 1 - 3 } after & $\mathbf{1 3 . 8 0 8}$ & $\mathbf{1 . 0 4 9}$ & & & & \\
\hline
\end{tabular}

As seen from the table (4) that the "T" value is equal to "40.251", a value statistically significant at 0.01 level for the post test, where the average scores of trainees in the post "13.808", while the average scores of trainees in the application of before is "1.817 ", which shows the benefit of trainees from training and knowledge of drawing Pattern, which contains the training program are clear, and thus achieved the second hypothesis.

\section{The third hypothesis: is as follows:}

"There are significant differences between the average scores of trainees in the knowledge gained with special implementation techniques before and after training for the post test."

To verify the validity of this hypothesis " $\mathrm{T}$ " test has been applied and the following table illustrates this:

Table (5) significant differences between the mean scores of the trainees in the knowledge gained special Implementation techniques before and after training

\begin{tabular}{|c|c|c|c|c|c|c|}
\hline $\begin{array}{c}\text { Enforcement } \\
\text { techniques }\end{array}$ & $\begin{array}{c}\text { Mean } \\
\text { "m" }\end{array}$ & $\begin{array}{c}\text { Standard } \\
\text { Deviation } \\
\text { "sd" }\end{array}$ & $\begin{array}{c}\text { Number of } \\
\text { respondents } \\
\text { "n" }\end{array}$ & $\begin{array}{c}\text { Degree } \\
\text { of } \\
\text { freedom } \\
\text { "df" }\end{array}$ & $\begin{array}{c}\mathrm{T} \\
\text { value }\end{array}$ & $\begin{array}{c}\text { Significance } \\
\text { level and } \\
\text { direction }\end{array}$ \\
\hline before & $\mathbf{2 . 3 4 2}$ & $\mathbf{1 . 1 6 0}$ & $r$ & rq & $\mathbf{3 8 . 7 5 0}$ & $\begin{array}{c}0.01 \text { for } \\
\text { dimensional }\end{array}$ \\
\cline { 1 - 3 } after & $\mathbf{1 4 . 4 0 9}$ & ,, v v & & & & \\
\hline
\end{tabular}


As seen from the table (5) that the "T" value is equal to "38.750", a value statistically significant at 0.01 levels for the post test, where the average scores of trainees in the post "14.409" while the average scores of trainees in the application before is "2.342", which shows the benefit of trainees from training and knowledge of techniques and implementation contained in the training program are clear, and thus achieved the third hypothesis.

\section{Hypothesis IV: the fourth hypothesis states as follows:}

"There are significant differences between the average scores of trainees in the gained knowledge before and after training for the post test" and to verify the validity of this hypothesis "T" test has been applied and the following table illustrates this:

Table (6) significant differences between the mean scores of the trainees in the knowledge acquired before and after training

\begin{tabular}{|c|c|c|c|c|c|c|}
\hline $\begin{array}{c}\text { Total } \\
\text { cognitive } \\
\text { test }\end{array}$ & $\begin{array}{c}\text { Mean } \\
\text { "m" }\end{array}$ & $\begin{array}{c}\text { Standard } \\
\text { Deviation } \\
\text { "sd" }\end{array}$ & $\begin{array}{c}\text { Number of } \\
\text { respondents } \\
\text { "n" }\end{array}$ & $\begin{array}{c}\text { Degree } \\
\text { of } \\
\text { freedom } \\
\text { "df" }\end{array}$ & $\begin{array}{c}\text { T } \\
\text { value }\end{array}$ & $\begin{array}{c}\text { Significance } \\
\text { level and } \\
\text { direction }\end{array}$ \\
\hline before & $\mathbf{4 . 1 5 9}$ & 1,1 & r. & rq & $\mathbf{2 0 . 7 2 4}$ & $\begin{array}{c}0.01 \text { for } \\
\text { dimensional }\end{array}$ \\
\cline { 1 - 3 } after & $\mathbf{2 8 . 2 1 7}$ & $\mathbf{6 . 2 2 9}$ & & & & \\
\hline
\end{tabular}

As seen from the table (6) that the value of "T" is equal to "20.724", a value statistically significant at 0.01 level for the post test, where the average scores of trainees in the post "28.217", while the average scores of trainees in the application before " 4.159 ", which shows the benefit of trainees from training and knowledge contained in the training program are clear. Thereby achieving a hypothesis IV, are consistent result with all the studies that addressed the impact of training to increase knowledge and information of individuals. As emphasizes by " Ali, 1992" that training an important step in the development plan to correct, amend and develop the overall knowledge and information about the individual and methods of work and requirements.

\section{Hypothesis V: the fifth hypothesis states as follows:}

"There are significant differences between the average scores of trainees in the skills acquired on forging the Pattern before and after training for the post test". 
To verify the validity of this hypothesis "T" test has been applied, and the following table illustrates this:

Table (7) significant differences between the mean scores of the trainees in the acquired skills on draw a sample before and after training

\begin{tabular}{|c|c|c|c|c|c|c|}
\hline $\begin{array}{c}\text { Graphic } \\
\text { form }\end{array}$ & $\begin{array}{c}\text { Mean } \\
\text { "m" }\end{array}$ & $\begin{array}{c}\text { Standard } \\
\text { Deviation } \\
\text { "sd" }\end{array}$ & $\begin{array}{c}\text { Number of } \\
\text { respondents } \\
\text { "n" }\end{array}$ & $\begin{array}{c}\text { Degree } \\
\text { of } \\
\text { freedom } \\
\text { "df" }\end{array}$ & $\begin{array}{c}\mathrm{T} \\
\text { value }\end{array}$ & $\begin{array}{c}\text { Significance } \\
\text { level and } \\
\text { direction }\end{array}$ \\
\cline { 1 - 2 } before & $\mathbf{1 . 3 0 0}$ & $\mathbf{1 . 0 0 4}$ & r. & rq & $\mathbf{3 0 . 1 5 0}$ & $\begin{array}{c}0.01 \text { for } \\
\text { dimensional }\end{array}$ \\
\cline { 1 - 3 } after & $\mathbf{1 3 . 5 3 7}$ & $\mathbf{2 . 1 3 4}$ & & & & \\
\hline
\end{tabular}

As seen from the table (7) that the value of "T" is equal to "30.150", a value statistically significant at 0.01 level for the post test, where the average scores of trainees in the post "13.537", while the average scores of trainees in the application before is "1.300", which shows the benefit of trainees from the special skills of the pattern and included in the training program, thereby achieving the fifth hypothesis.

Terminals VI: the sixth hypothesis states as follows:

"There are significant differences between the average scores of trainees in the skills gained in the implementation of techniques before and after training for the post test".

To verify the validity of this hypothesis "T" test has been applied and the following table illustrates this:

Table (8) significant differences between the mean scores of the trainees in the acquired skills of the implementation techniques before and after training

\begin{tabular}{|c|c|c|c|c|c|c|}
\hline $\begin{array}{c}\text { Enforcement } \\
\text { techniques }\end{array}$ & $\begin{array}{c}\text { Mean } \\
\text { "m" }\end{array}$ & $\begin{array}{c}\text { Standard } \\
\text { Deviation } \\
\text { "sd" }\end{array}$ & $\begin{array}{c}\text { Number of } \\
\text { respondents } \\
\text { "n" }\end{array}$ & $\begin{array}{c}\text { Degree } \\
\text { of } \\
\text { freedom } \\
\text { "df" }\end{array}$ & $\begin{array}{c}\mathrm{T} \\
\text { value }\end{array}$ & $\begin{array}{c}\text { Significance } \\
\text { level and } \\
\text { direction }\end{array}$ \\
\hline before & $\mathbf{1 . 9 1 2}$ & $\cdot, \wedge \wedge \cdot$ & $r \cdot$ & rq & $\mathbf{3 5 . 2 1 1}$ & $\begin{array}{c}0.01 \text { for } \\
\text { dimensional }\end{array}$ \\
\cline { 1 - 3 } after & $\mathbf{1 3 . 0 1 7}$ & $\mathbf{1 . 2 6 2}$ & & & & \\
\hline
\end{tabular}


As seen from the table (8) that the value of "T" is equal to "35.211", a value statistically significant at 0.01 level for the post test, where the average scores of trainees in the post "13.017", while the average scores of trainees in the application before "1.912", which shows the benefit of trainees of the skills for implementation and included in the training program, thereby achieving the sixth hypothesis.

\section{Terminals VII: the seventh hypothesis states as follows:}

"There are significant differences between the average scores of trainees in the acquired skills before and after training for the post test"

To verify the validity of this hypothesis " $\mathrm{T}$ " test has been applied and the following table illustrates this:

Table (9) Significance of the differences between the mean scores of the trainees in the acquired skills before and after training

\begin{tabular}{|c|c|c|c|c|c|c|}
\hline $\begin{array}{c}\text { Total } \\
\text { skills } \\
\text { test }\end{array}$ & "m" & $\begin{array}{c}\text { Standard } \\
\text { Deviation } \\
\text { "sd" }\end{array}$ & $\begin{array}{c}\text { Number of } \\
\text { respondents } \\
\text { "n" }\end{array}$ & $\begin{array}{c}\text { Degree } \\
\text { of } \\
\text { freedom } \\
\text { "df" }\end{array}$ & $\begin{array}{c}\text { T } \\
\text { value }\end{array}$ & $\begin{array}{c}\text { Significance } \\
\text { level and } \\
\text { direction }\end{array}$ \\
\hline before & $\mathbf{3 . 2 1 2}$ & $\mathbf{1 . 5 3 1}$ & r. & rq & $\mathbf{3 4 . 0 1 5}$ & $\begin{array}{c}0.01 \text { for } \\
\text { dimensional }\end{array}$ \\
\cline { 1 - 2 } after & $\mathbf{2 6 . 5 5 4}$ & $\mathbf{3 . 5 3 0}$ & & & & \\
\hline
\end{tabular}

As seen from the table (9) that the value of "T" is equal to "34.015", a value statistically significant at 0.01 level for the post test, where the average scores of trainees in the post "26.554", while the average scores of trainees in the application before "3.212", which shows the benefit of trainees of the skills included in the training program. Thereby achieving the seventh hypothesis, this result agrees with studies that have been used in the training of individuals raising the efficiency of the process. As emphasizes by "Ahmed, 1990" that training aimed at development, technical and behavioral skills which are necessary for individuals to enable them to achieve themselves.

From the abovementioned, the training raises the efficiency of personnel, knowledge and leads to increased production and reduces spoilage and costs. 


\section{Research Recommendations:}

From the results it is recommended that:

1 - The process of training should be at intervals not to exceed five years to cope with the rapid developments in the garment industry.

2 - Building training programs for various products to raise the efficiency of the trainees.

3 - Use of computers for preparing special programs for training planning and follow-up within the garment factories.

\section{References}

1. Abdel-Moneim Junaid: Department of Human Resources - Faculty of Commerce - Tanta 1996.

2. Ahmed Sayed Mostafa, training for managers for the Development of Human Resources - Management Journal - Volume XXII - No. III - January -1990 AD.

3. Bass Randall Chambless Jim, Job Corps staff assessment of required staffdevelopment training -PHD -The university of Mississippi-1997.

4. Hatem Mahmoud Ahmed Rufai, The Effectiveness of a training program for the development of basic skills for the manufacture of clothing for members of the armed forces recruits - unpublished Master Thesis - College of Home Economics - Helwan University -1999.

5. Mohamed Abdel Wahab, Aida Sayed address: Department of Human Resources - Faculty of Commerce - Ain Shams University, -2002.

6. Mohammed Ayman Al-Latif: Human resources management in the workplace, "the scientific basis and practical application" - Faculty of Commerce - Cairo University - i 12007.

7. Mohamed Abdel-Khalek MM: professional development for teachers "of contemporary trends - Entrances - Strategies," University Book House - Al Ain United Arab Emirates -2002.

8. Peterson David bruce :Skill Learning and behavior change in an individually tailored management coaching and training program -PHD - The university of Minnesota -1993.

9. Peaceful: Department of Human Resources - Library curious - Cairo -1992.

10. www.hrdf.org.sa

11. www.suwaidan.com

12.www.alhassan.owno.com

13.www.hrdiscussion.com

14.http://www.alhadag.com/column.php?id=422 


\section{ملخص البحث}

\section{فاعلية برنامج تدريبى لأنتاج الملابس الخارجية الصريمى لخدمة الصناعات الصغيرة}

$$
\text { ويهرف البحث الى: }
$$

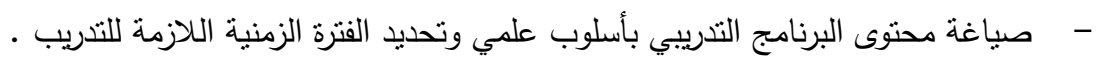
- - تحديد مدى فاعلية برنامج تدريبي قائم على أسس علمية لإكساب الخريجات المعارف والمهارات الخاصـة

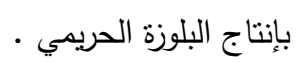

- - أعداد وتأهيل الخريجين وأكسابهم المعارف والمهارات التى يتطلبها سوف العمل.

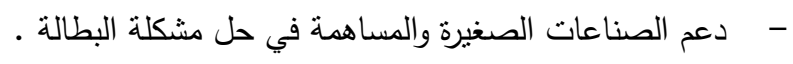
وتم أستخدام أدوات البحث الأتية للوصول الى الأهداف المرجوة:

$$
\begin{aligned}
& \text { - - - البرنامج التدريبي - } \\
& \text { - - اختبار تحصيلي معرفي (قبلي / بعدي) . }
\end{aligned}
$$

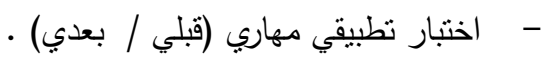

$$
\begin{aligned}
& \text { - }
\end{aligned}
$$

وتوصلت الباحثة لوجود فروق دالة أحصائيا بين منتسط الدرجات القبلية والبعدية فى كل من المعارف والمهارات التىى يتضمنها البرنامج بالنسبة لرسم البانرون وتقنيات التنفيذ لصالح الأختبار البعدى مما يدل على نجاح البرنامج التدريبى ورفع كفاءة المتدربين. 